\title{
Contributions to a Brazilian Code of Conduct for Fieldwork in Geology: an approach based on Geoconservation and Geoethics
}

\author{
KÁTIA L. MANSUR ${ }^{1}$, LUIZA C.M.O. PONCIANO ${ }^{2}$ and ALINE R.S.F. DE CASTRO ${ }^{1}$ \\ ${ }^{1}$ Universidade Federal do Rio de Janeiro/UFRJ, Instituto de Geociências/IGEO, Departamento de Geologia e \\ Museu da Geodiversidade, Av. Athos da Silveira Ramos, 274, 21941-916 Rio de Janeiro, RJ, Brazil \\ ${ }^{2}$ Universidade Federal do Estado do Rio de Janeiro/UNIRIO, Instituto de Biociências/IBIO, \\ Departamento de Ciências Naturais, Laboratório de Tafonomia e Paleoecologia Aplicadas/ \\ LABTAPHO, Av. Pasteur, 458, Sala 504, 22290-255 Rio de Janeiro, RJ, Brazil
}

Manuscript received on January 9, 2017; accepted for publication on February 13, 2017

\begin{abstract}
When considering the numerous events that have prohibited the development of scientific projects or caused destruction of outcrops, it is clear that there is rapidly increasing necessity to define a Brazilian Code of Conduct for geological fieldwork. In general, this destruction is attributed to lack of knowledge as to the relevance of geological sites. The aim of this Code of Conduct is to guide geologists to adopt good practices during geoscience activities. Proposed guidelines are based on Codes of Conduct from other countries, mainly Scotland and England, on situations described in papers and on the personal experience of the authors. In this paper 29 points are suggested, in order to guarantee that fieldwork is conducted in accordance with geoethics, geoconservation and sustainability values. The proposal is structured in three parts: (1) Behavior and practices in respect to local traditions and providing information to the population; (2) Measures to minimize degradation on outcrops; and (3) Safety. The proposal seeks to broaden the debate on the need for responsible behavior during fieldwork, in order to promote respect for geodiversity. Through this code, Brazilian geoscientists will be able to contribute to the conservation of geological heritage and of outcrops with special educational relevance.
\end{abstract}

Key words: geoethics, geoconservation, code of conduct, sustainability principles, geoheritage, fieldwork.

\section{INTRODUCTION}

The definition of a Brazilian Code of Conduct for Geoscience activities in Brazil is becoming increasingly necessary, especially when we consider the many events that have prohibited

Correspondence to: Kátia Leite Mansur

E-mail:katia@geologia.ufrj.br

* Contribution to the centenary of the Brazilian Academy of Sciences. several scientific projects or caused the destruction of outcrops with educational, touristic or scientific value.

Events such as these still occur, even in countries where codes of conduct have been implemented. MacFadyen (2011a) highlights the irresponsible collection of paleontological material at a geosite of special scientific interest in Scotland, resulting in the accumulation of several fragments 
of fossils that were damaged during the collection, which were subsequently abandoned, probably because they didn't represent complete specimens. MacFadyen (2011a) also presented the case of a large hole opened in the search for trilobites in the southwest of Scotland, causing damage to a geosite with aesthetic, educational and scientific value. The conservation measures undertaken to protect the remaining fossils in situ were to cover the area with a cloth and fill the hole with rocks and soil of the region.

This demonstrates that, besides the existence of rules, there is a need for a wide discussion among geocientists on these issues and the application of strategies for the geoconservation of geoheritage with educational and scientific value. Thus, it is possible to raise awareness as to the need for maintenance of the integrity of such places, valorization of the educational use of their attributes by students and researchers and their enjoyment by the population in general, which can benefit through geotourism.

For these reasons, this paper proposes a Brazilian Code of Conduct for fieldwork in Geology. The aim is to present guideline suggestions for the adoption of good practices during geoscience related activities, adapted to the Brazilian reality. The proposed guidelines were based on Codes of Conduct from other countries, mainly Scotland (Scottish Fossil Code - Scottish Natural Heritage 2016) and England (Geologists' Association 1995, Fieldwork Safety Code of Practice - Birkbeck College 2016, Safety Code of Practice 32: Fieldwork - University of Reading 2016; Policy $\&$ Guidance for the Safe Conduct of Fieldwork The University of Nottingham 2016; the "Student declaration form for field safety and medical fitness" - University of Bristol 2016), on situations reported in published papers (MacFadyen 2007, 2008, 2011a, b, Fedonkin et al. 2009) and authors' experiences in the field.

\section{GEOETHICS AND GEOCONSERVATION}

The International Association for Promoting Geoethics (IAPG 2012) defines geoethics as follows: Geoethics: (a) consists of the research and reflection on the values upon which to base appropriate behaviors and practices, wherever human activities interact with the geosphere; (b) deals with the ethical, social and cultural implications of Earth Sciences education, research and practice, providing a point of intersection for Geosciences, Sociology, Philosophy and Economy; (c) represents an opportunity for Geoscientists to become more conscious of their social role and responsibilities in conducting their activity; and (d) is a tool to influence the awareness of society regarding problems related to geo-resources and geo-environment (IAPG website: http://www. geoethics.org; $1^{\text {st }}$ access: January 2017).

In this same sense, Vasconcelos and Imbernon (2015) discussed the internalist model of Science, characterized by a separation between the work undertaken by scientists and the social, environmental, economic and political context within which it takes place. For these authors "In this context arises Geoethics, due the growing awareness of environmental problems, translated from the need for an ethical attitude with the Geosphere, from the social responsibility of geologists. Geoethics is an interdisciplinary field between Geosciences and Ethics...”.

In the same approach, Grunwald (2015) lists nine sustainability principles relevant to Geoethics: (a) protection of human health; (b) securing the satisfaction of basic needs; (c) sustainable use of renewable resources; (d) sustainable use of nonrenewable resources; (e) sustainable use of the environment as a sink; (f) avoidance of unacceptable technical risks; $(\mathrm{g})$ conservation of nature's cultural functions; (h) participation in societal decision-making processes; and (i) equal opportunities. 
According to Raworth (2012), sustainable development requires that humanity's use of natural resources remains within environmental limits. This means recognizing that many Earth systems have critical natural thresholds or gradients of increasing risk - such as climate change, loss of biodiversity, and land use change - which must not be crossed if the Earth is to remain in its current state, which has enabled many human civilizations to arise, develop, and thrive. Between a social foundation that protects against critical human deprivations, and an environmental ceiling that avoids critical natural thresholds, lies a safe and just space for humanity (Figure 1). This is the space where both human well-being and planetary well-being are assured, and their interdependence is respected.

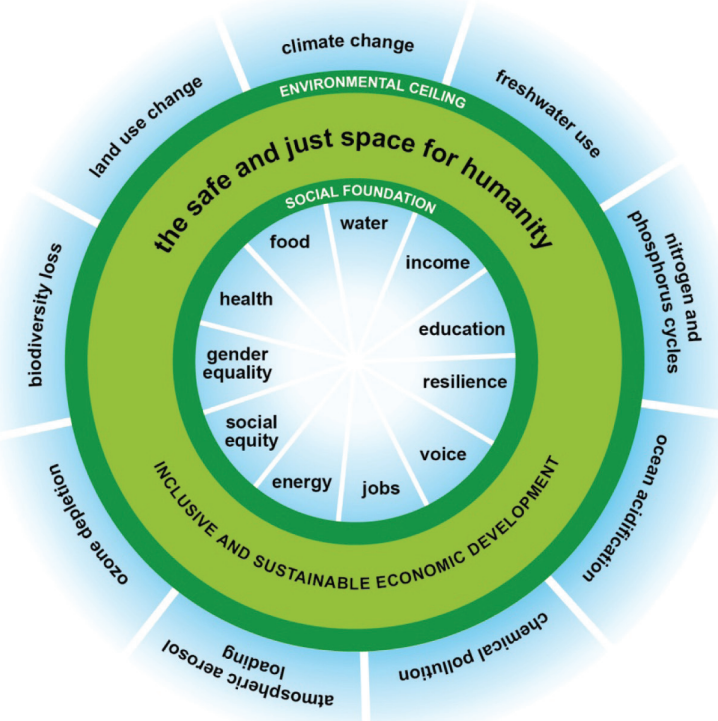

Figure 1 - The nine dimensions of the environmental ceiling are based on the planetary boundaries. Source: Raworth (2012).

Butler (2015) lists a variety of damage suffered by valuable rock outcrops that was caused in the name of science. For him, scientists, funders and publishers must push forward a stronger code of ethics. He presents the use of core sampling in paleomagnetism, microgeochemical and archaeological studies and alerts to "destructive sampling ethics". He concludes: "Sampling restrictions are common in the biological sciences. Ethical considerations prohibit zoologists from collecting rare birds' eggs, for example. Geoscientists must adopt a similar approach. Indiscriminate rock coring and other destructive sampling methods risk reputational damage not just to the scientists, but also to the institutions that employ them and the journals that publish their science".

One of the most important geosites in the world, the Giant's Causeway, in Ireland, had an area damaged through rock coring. As a World Heritage Site and part of the Giant's Causeway, it was highlighted in the "Causeway Coast and World Heritage Site Management Plan 2013 2019" (Northern Ireland Environment Agency, 2013) that damage had been caused through rock coring practices. The Geological Survey of Northern Ireland (GSNI) and the Northern Ireland Environment Agency (NIEA) in conjunction with the National Trust have recognized this and produced a position statement addressing the issue, which can be consulted at http://giantscauseway. ccght.org/rock-coring-world-heritage-site/.

The neologism "Geovandalism" has been used in many texts on geoconservation to explain the destruction of features on outcrops through sampling for science, for private collection or ignorance of the importance of the site. Rowan (2008) described as "professional geovandalism" the use of a hammer to collect Archean bacterial mats in the Pongola Supergroup, in South Africa. MacFadyen (2007) presented a scathing article about core sampling entitled "When coring = GEOVANDALISM".

On the other hand, Peppoloni and Di Capua (2012) alert that geoethics does not exist without real awareness of the scientific community as to the cultural value of the Geosciences, with the perspective of the spiritual and economic progress of humanity. Their ideas can be summarized as follows: "Otherwise, there is the risk that geoethics 
will become just another bureaucratic constraint on the freedom of research and actions, a new set of bonds imposed but not perceived in their value, to limit practices and ideas. Geoethics can become a pretext to lock up the researcher and the whole of society in a moralistic way, in the contraposition between what is right and what is wrong, what we have to do, and what not to do".

Both of the concepts, Geoethics and Geoconservation, are new approaches in Geosciences. It is important and necessary to discuss their large scale application under penalty of loss of geodiversity with scientific, cultural, educational and touristic values (Brilha 2016, Peppoloni and Di Capua 2016).

In many countries the behavior of professionals during fieldwork is oriented by a Code of Conduct. These documents also include aspects related to safety. Lisle et al. (2014) presented methods and material necessary in geological mapping. They alert to safety risks ("Do not proceed until you have read this section!"), usually classified into six types: fall from steep slope; struck by falling rock or splinters from hammering; drowning after being swept away by waves, tides or floods; cannot be reached by emergency services; exposure to extreme chill from sudden drop in temperature; and motoring accident. In Brazil, we can also include heat stroke, resulting from prolonged exposure to excessive heat and characterized by cessation of sweating, severe headache, high fever, hot dry skin, and in serious cases collapse and coma. These authors also emphasize the need to obtain authorization from the owners to enter their lands and for rock hammer, for example.

\section{THE NEED FOR A BRAZILIAN CODE OF CONDUCT}

Many cases of problems caused by inappropriate use of geosites due to fieldwork have been reported in Brazil. A remarkable and recent fact was the prohibition of sample collection imposed by landowners along a railway where Devonian fossils of the Paraná Basin outcrops were found. A few years ago fines were imposed by the company that manages the railway because rock fragments were found on the tracks after irresponsible sampling during fieldwork. After this incident, the owners began to inhibit access to the fossil site, which used to be visited very often by educational and research institutions from several states. Moreover, in this same place, the numerous visits without the development of heritage education projects for residents generated another negative effect. Children from the nearby communities began to offer visitors fossils they had collected, and to indicate the location of the fossiliferous horizons, in exchange for payment. In both cases, the removal of fossils without concern or interest for the conservation of the geosite or the preservation of stratigraphic or taphonomic information generated threats to the paleontological research and geological heritage.

In Brazil, graffiti on rocks and in caves is another recurrent problem (Figure 2). The caves are also often vandalized by the withdrawal of speleothems and religious practices.

Researchers have also been identified as responsible for damage to outcrops, which have

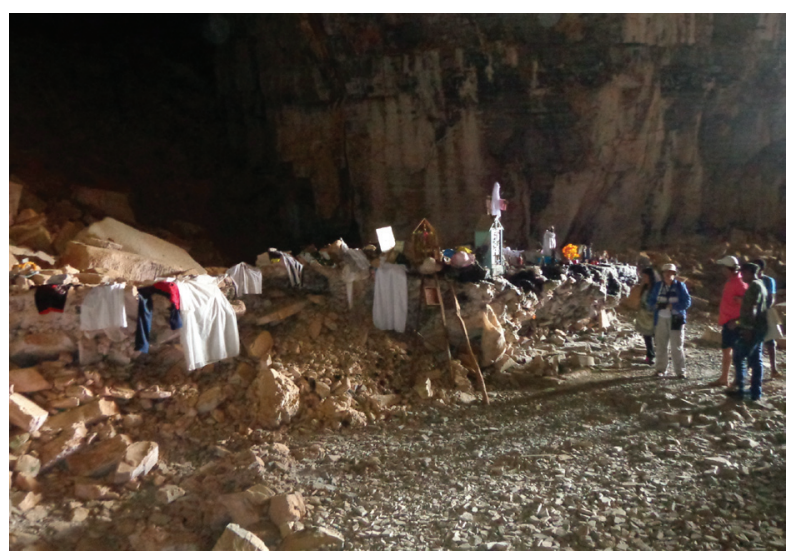

Figure 2 - Photo of religious offerings, remains of molten candle and soot in "Lapa dos Brejões" Cave, Chapada Diamantina, Bahia, Brazil (Photo: Rafael Albani, 2016). 
been systematically damaged through sampling, like the example of Fazenda Arrecife, located in the state of Bahia (Figure 3). In this example the warning about future surveys, identified by red paint marks at six possible drilling sites on the best and most didactic exposition of the outcrop, prevented the removal of core samples from one of the most important scientific, aesthetic and educational neoproterozoic stromatolite geosites in Brazil.

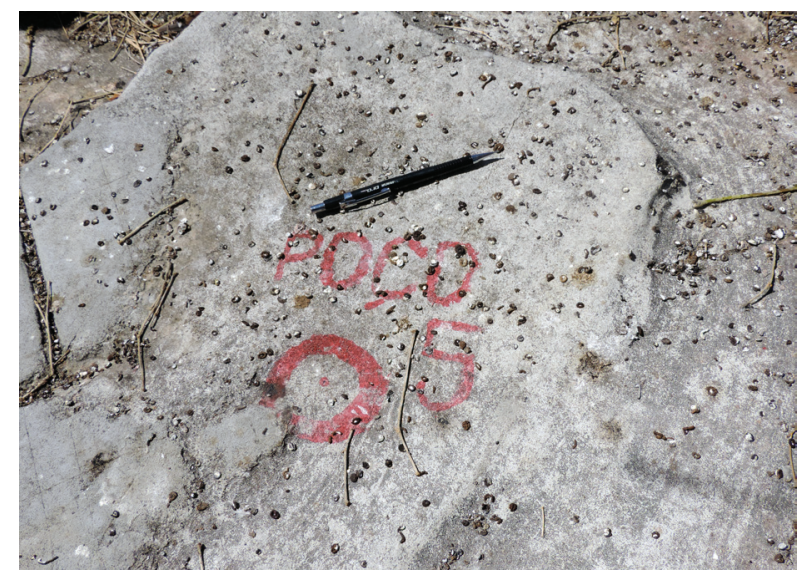

Figure 3 - One of the marks made with permanent paint to indicate a possible drill hole on one of the most important stromatolite geosites in Brazil. This denouncement by the scientific community indicating the imminent damage prevented the realization of the holes (Photo: Kátia Mansur, 2013).

Another aspect that cannot be overlooked when it comes to code of conduct is the issue of maintaining staff safety during the fieldwork. Two tragic cases took place in Brazil that led to the death of students in 2006 (Federal University of Rio Grande do Norte - UFRN) and 2013 (Federal University of Pará - UFPA). It is therefore important to consider appropriate behavior and safety during activities. In the case of UFRN, some students disobeyed the teacher's instructions and passed through a region with loose rock blocks that were dislodged as the group passed over them. The rocks hit a student on the head leading to his death. In the case of UFPA, some students suffered sunstroke during fieldwork and, according to what was verified, one of the students became disoriented and got lost in the region. The student was found dead days later, the cause of death being dehydration.

\section{BRAZILIAN LEGISLATION ON GEOLOGICAL HERITAGE}

The legislation concerning exploitation of mineral resources and collection of scientific samples, including fossils, is huge and diverse in Brazil, but not very effective, due to the lack of law enforcement. The virtual absence of control results in many students and even professionals not being familiar with the legal rules regarding the collection of material from geological and paleontological sites. It is worth mentioning that for the purposes of this paper, paleontological heritage is considered part of geological heritage.

Before beginning fieldwork, it is essential that all members of the research team are enlightened as to the main aspects of the Brazilian legislation. In addition to the importance of this previous knowledge, the fieldwork should be preceded by detailed planning that includes, among other aspects, an assessment of the necessary amount of material to be extracted, according to the most appropriate methods. This planning can prevent potential risks to the safety of the geoscientists and provide clear data to establish a good relationship with the local population.

Protection of fossiliferous deposits was first mentioned on March $4^{\text {th }}, 1942$, when President Getúlio Vargas signed the Decree - Law 4146, after advice from the paleontologist Llewellyn Ivor Price, from the National Department of Mineral Production (DNPM). In the first article of that decree, fossil deposits are described as property of the Nation. The extraction of fossils depends on preventive authorization from the DNPM that also oversees the exploitation of fossil deposits. National and State museums and similar official 
institutions, i.e., universities, and federal and state institutes, should send notice of the completion of fieldwork to DNPM (Brasil 1942). This Decree defines that any person that explores fossil deposits without express authorization from the DNPM will be subject to arrest as a spoiler of the national scientific heritage.

The participation of foreigners in scientific fieldwork in Brazil is regulated by Decree 98830/1990, which concerns the collection methods of scientific data and materials (biological and mineral specimens and objects of the native and popular culture of past and present). The MCT Ordinance 55/1990 normalizes this Decree (Brasil 1990a, b).

There are several legal norms which regulate the research and collection of geological and paleontological material and protect the natural heritage in Brazil. These rules include: (a) The Constitution of Brazil/1988: articles 20, 23, 24 and 216; (b) Laws: 6.938/1981; 7.347/1985; 7.804/1989; 9.605/1998; 9.985/2000; 11.046/2004 (c) Decrees: 25/1937; 2.848/1940; 3.689/1941 (articles 163 and 180); 80.978/1977; 8.176/1991; 3.166/1999; 7.092/2010; Convention Concerning the Protection of the World Cultural and Natural Heritage (Paris 1972), adopted by Brazil in 1989, through Decree 98.830/1990; (d) Decrees-Law: 4.146/1942; 227/1967; 72.312/1973.

The newest official legislation document on fossils and fossiliferous sites in Brazil (DNPM 107/2010) presents a broad legal analysis on DNPM's responsibilities and legal duties. It recognizes the responsibility of the DNPM to protect fossil specimens and fossiliferous sites (Item X). In Item XI, this document assigns the task of classifying fossils and fossiliferous sites as heritage to IPHAN (Instituto do Patrimônio Histórico e Artístico Nacional - National Institute of Historic and Artistic Heritage). Both federal institutions can protect this heritage through the
Protected Area Unit named Natural Monuments (Item XII).

Since 1999 the Law Project 1.859 has been under analysis by the Congress, with the proposal to declare fossiliferous sites as Natural Monuments, to be classified by DNPM as: (a) Open - when the conservation of fossils is compatible with controlled visitation activities and research; or (b) Integral Protection - when the special characteristics of the site justify its exclusive use for research activities. The criteria for this classification take into account the scientific, ecological and touristic relevance of the site, besides its regional, national or global relevance (Mansur 2010).

For the Attorney General's Office in São Paulo, though fossils are often associated with other mineral assets, the DNPM permission given to mining companies is only for the extraction of the permitted mineral substance, and does not include fossils, which require specific authorization from the institution in order to be extracted (Mansur 2010).

It should be emphasized that natural heritage, including geological heritage, is considered part of Brazilian cultural heritage, representing cultural appropriation and, at the same time, a conceptual unit, and so, the differentiation between natural and cultural heritage is unnecessary.

As a result, the natural categories have always been included in the Brazilian legislation related to cultural heritage (Cachão and Silva 2004, Souza et al. 2007). However, Pereira et al. (2008) highlight that the protection given to geological heritage by recognizing its cultural dimension isn't effective in Brazil, because there are no specialized professionals to assess the geological peculiarities of cultural sites. The same authors point out that categories of the National System of Protected Areas (Sistema Nacional de Unidades de Conservação - SNUC, in Portuguese), created by Law 9.985/2000, are the most adequate for the conservation of geological heritage. Among 
the aims of SNUC is the protection of natural landscapes with notable scenic importance and relevant characteristics regarding geological, geomorphological, speleological, archaeological, paleontological and cultural aspects (Brasil 2000). However, geological features are still undervalued in Brazil's protected areas, since the protection of biodiversity is the main goal.

Mansur (2010) also highlights the concept of Natural Monuments as one of the most appropriate geological heritage tools of the SNUC, and lists the following examples: (a) Monumento Natural dos Pontões Capixabas (Natural Monument of Capixaba Pontoons), in the state of Espírito Santo (federal protected area); (b) Monumento Natural das Árvores Fossilizadas (Natural Monument of Fossilized Trees), in the state of Tocantins, the Monumento Natural Vale dos Dinossauros (Natural Monument of Valley of the Dinossaurs), in the state of Paraíba, the Monumento Natural Gruta do Lago Azul (Natural Monument of the Blue Lake Grotto), in the state of Mato Grosso do Sul and the Monumento Natural Geiseritos de Anhembi (Natural Monument of Anhembi Geysers), in the state of São Paulo (state protected areas); and (c) Monumento Natural dos Costões Rochosos (Natural Monument of Rocky Headlands) and Monumento Natural dos Morros do Pão de Açúcar e da Urca (Natural Monument of Sugar Loaf and Urca Mountains), in the state of Rio de Janeiro (municipal protected area).

Ponciano et al. (2011) mention other categories used by SNUC that have also been used for the protection of geological heritage, such as parks (at national, state or municipal levels) and environmental protection areas (APAs). The question is that special biodiversity content is required for these kinds of protected area, and, in general, an old mine or geological site is a degraded area, without biodiversity value, which precludes the use of SNUC tools. There are few Protected Areas, of essentially paleontological characteristics, such as the Paleontological Park of São José de Itaboraí, in the State of Rio de Janeiro, an old mining area. The APA Carste de Lagoa Santa (in the state of Minas Gerais) is also an example of a Protected Area of great historical and scientific importance for paleontology, because it contains Pleistocene megafauna fossils and the oldest remains of a hominid in Brazil.

We also have examples of cultural heritage geosites nominated by IPHAN, such as the Fossil Forest of Poti River in Teresina (in the state of Piauí), the impact craters of Colônia (in the state of São Paulo), Vista Alegre (in the state of Paraná) and the rocky shores of Armação dos Búzios (in the state of Rio de Janeiro) (Mansur 2010). This type of protection may be applicable to sites related to mining heritage or located in degraded areas.

\section{CONSIDERATIONS ON IN SITU AND EX SITU GEOCONSERVATION IN BRAZIL}

The waste of fossiliferous material during the selection of samples highlighted by MacFadyen (2011a) also occurs in Brazil, both in fieldwork and in educational or research institutions. Samples not selected for research are generally used for teaching in the same institution, or simply discarded. Instead, the excess material could be offered as a donation to other teaching and research institutions, or to a public institution in the region where the material was collected (eg. a museum). Moreover, several samples of fossils, minerals and rocks are often discarded while still in the field, despite their potential importance for institutions that do not have similar pieces in their scientific or teaching collections (Ponciano et al. 2011).

This material could also be exposed on a virtual database for interested researchers asking for a donation or exchange. Existing databases could be used for this purpose, such as the CPRM - Geological Survey of Brazil (http://geosgb.cprm. gov.br/). 
The additional samples could also be donated to elementary or secondary schools, in order to encourage the teaching of Geology and Paleontology in courses of Sciences, Biology and Geography. It is important to mention the example of the Didactic Collections Project of DNPM which aims to promote Brazilian geological heritage through the distribution of fossils of fishes, plants and insects which have been found at the geosites of the Araripe Basin. These samples are obtained from the seizure of material collected without authorization (illegal trade in fossils), or paleontological material saved during mining activities.

Another cause of destruction of geological heritage in situ is the implementation of major infrastructure work and projects (such as power plants, transmission lines, pipelines, roads, resorts, etc). Depending on the management of companies and requirements of environmental authorities, this type of work could even provide a rare opportunity to discover new outcrops or fossil horizons, but unfortunately this is not the reality in our country. A solution for these cases is the development and implementation of geological heritage rescue programs (Stock-da-Rosa et al. 2003, Furukawa et al. 2010, Ponciano et al. 2011). In the case of roads, several good outcrops were recently covered with grass or cement, which made their study and use in field trip classes non-viable. However, it must be taken into account that rescue should not be assumed as the best alternative in every situation. The possibility of alternative locations for the enterprises should also be studied. The destruction of geological heritage in situ can prevent future discoveries of scientific relevance, so it should be considered in the light of courses of precautionary criteria.

All projects subject to environmental licensing in Brazil require studies by archaeologists to verify the possible existence of prehistoric sites and objects that might be affected by the work. A situation often found is the description of geological / fossiliferous sites by archaeologists, frequently resulting in misleading descriptions of these types of sites, without this problem being considered carefully by the authorities. Thus, the teams of agencies responsible for environmental licensing still need to be better informed about the differences and peculiarities of collection methodologies and fieldwork by geologists, paleontologists and archaeologists, as archaeologists may not have know-how in geological issues. Outcrops or sedimentary deposits evaluated only by archaeologists cannot be considered afossiliferous without at least a joint assessment being made by a geologist or a paleontologist.

Usually only the archaeological heritage is recovered during the execution of large scale work and structures. Many valuable sites and elements of geodiversity continue to be destroyed before their presence is recorded. The destruction of Brazilian geological heritage will continue to occur, until geologists and paleontologists are involved in environmental licensing procedures applied by IBAMA and by state and municipal agencies.

\section{GUIDELINES FOR A BRAZILIAN CODE OF CONDUCT}

One of the main responsibilities of the researchers leading fieldwork should be to ensure the good behavior of team members in relation to the inhabitants of the visited area, especially with the land owners where the outcrops are located. Local customs and beliefs should be taken into consideration when establishing a constructive relationship with the population living in the areas surrounding geosites. These attitudes aim to prevent the occurrence of situations preventing further visits.

Prior to accessing outcrops, the land owner's permission must be requested and the objectives of the research explained, identifying the institution of 
the researchers, and establishing how many people will visit the site on the indicated dates. In the event of carrying out a collection, the motivation for the research should be clearly explained, so that the owners do not create false expectations in regard to the economic value of the material to be extracted, which could lead to destruction of the outcrop or prohibition of access to the geosite. It is very important to highlight to the public that fossils, rocks, minerals and soils lose part of their scientific value when removed from their place of origin without proper methodology. Furthermore, Brazilian fossils do not have economic value and cannot be sold because they are property of the Nation.

In the case of public land, it should be investigated to see if a geosite is a protected area, with rules for scientific research and sample collection, and which agency authorizations should be requested in advance of the fieldwork. For example, the Monumento Natural das Arvores Fossilizadas (Natural Monument of Fossilized Trees), created by the Ordinance NATURATINS 191/2008, has rules and procedures for authorization of scientific research and teaching activities, provided by the protected areas of the state of Tocantins.

We suggest 29 points in order to guarantee that fieldwork is conducted in accordance with geoethics, geoconservation, and sustainability values. Such proposal is detailed in three topics: (1) Measures related to behavior and practices; (2) Measures to minimize degradation on outcrops; and (3) Safety measures.

\section{BEHAVIOR AND PRACTICES}

- In order to carry out geological surveys, it is necessary to ask permission from the landowners or the management institution, making clear the objective of the survey.

- Before the beginning of fieldwork, all team members must know the legal implications concerning the removal of fossils and other legally protected materials.

- After visiting the outcrops, any changes made at the locations should be reversible and/or minimized, in order to maintain the conditions found before the execution of the fieldwork. Therefore, all equipment and materials used, particularly waste produced during the extraction of samples, should be removed from the geosite. Fences and gates of the farms should be left as found.

- All team members should be aware that they represent their institution / company and, as such, must behave appropriately.

- Local people, traditions and customs must be valued and respected.

- Results obtained through analysis of the collected material and studies performed on site should be disclosed to the owners of the land, local population and schools. It is suggested that educational activities (such as lectures and/or courses with the use of casts of the collected fossils, for example) are conducted in schools, universities and residents' associations, presenting information derived from the research, by using accessible language in order to promote public understanding. Duplicate samples could also be donated to local museums, schools and universities with the purpose of promoting the importance of the geosite and sites of geodiversity.

- Gutters draining rainwater, the track and roadside, as well as the rails of railways, must be kept free of any rock fragments that have been generated during the collection of material, preventing possible accidents.

- If collection of material is performed, the visual impact, at least in the areas of greater visibility, should be reduced, recovering them with the repositioning of displaced blocks or other material with similar 
composition and color as the soil or rocks of the region. This procedure is especially suitable for excavations, which should be fully covered for safety as well as aesthetic reasons.

- Damaging interference with local wildlife should be avoided. Plants and animals may inadvertently be displaced or killed through careless actions, as geosites are usually associated with other elements of natural heritage. Disturbances caused to the flora and fauna should be avoided in order to reduce possible damage to the environment. The production of noise must be kept to a minimum. The unnecessary removal of plants and animals must be avoided.

- The material collected from one site cannot be discarded at another, because it could lead to future misinterpretations.

- Any material that has been used for the construction of sidewalks, walls, bridges, buildings, or any other similar type of public or private structure should not be collected. Rocks, minerals and fossils are plentiful in cities and can be mapped for their use in heritage education projects, highlighting and disseminating their importance in the daily life of the urban population and promoting their geotouristic value. The removal of geodiversity elements which has been authorized for scientific reasons must be scheduled and carried out in an appropriate way, consolidating the material prior to its removal and recovering the structure with material similar to that which will be removed (Mcgowan and Challands 2013).

\section{MEASURES TO MINIMIZE DEGRADATION ON OUTCROPS}

- Students cannot be allowed to destroy outcrops during educational fieldwork.
Material should be collected in minimal quantity and, if necessary, only the rocks indicated by the fieldtrip guide should be hammered. Samples of educational collections can be used during fieldtrips for demonstration of the geodiversity found at the site, avoiding unnecessary removal of more material with each new visit. It should be carefully considered that very frequent collection visits of classes to the same outcrop could destroy the geological site and prevent its use by future generations.

- Sampling carried out with high impact equipment, such as hand drills, can cause great damage to geosites. According to MacFadyen (2007, 2011b) and the Geologists' Association (1995), when required, the drilling of holes should be made on less visible parts of the outcrop, without following a geometric pattern, and in a small amount. After collection, holes have to be closed by filling them with rock fragments (gravel) taken from the same type of rocks. For this reason, rock removal from the outcrop has to be avoided, and only loose fragments on the ground should be used. The remaining space should be completely filled by a mixture of small rock fragments with cement and / or resin, in order to reduce the visual impact of the sampling. "Respect the feelings of other geologists, who may have curbed their natural instincts and adhered to a "no hammering rule" at the same locality" (Geologists' Association 1995). Other suggestions of techniques for restoration or conservation of geosites can be found in Mansur et al. (2013).

- The list of registered and approved geosites of the SIGEP (Brazilian Commission of Geological and Paleobiological Sites http://sigep.cprm.gov.br/) must also be consulted before conducting fieldwork, 
as there are more than 100 Brazilian sites already included in the heritage list for their exceptional scientific, educational, cultural value. These geosites should receive particular attention, in order to be fully preserved.

- Outcrops should not be climbed unless this is essential to the development of the research, especially if the area is already suffering erosive phenomena.

- Outcrops are not to be permanently marked with numbers or symbols made with paint or pens because this "geological graffiti" jeopardizes the aesthetic, educational, cultural, and scientific value of geosites. Metallic pins surrounded by colored ribbons containing information about the location of the point are an option for temporary marks. After completion of the work, these pins must be removed, and the impact caused by them can be minimized if the natural fractures are used for their temporary fixation. Depending on the type of rock, chalk or water-soluble ink may be used for performing temporary marks.

- The removal of fossils, minerals or rocks should be avoided, unless their collection is essential for carrying out scientific research. Even for this purpose, collection of samples should be minimized by taking into consideration the nature of the study; the amount of material previously removed from the geosite and already collected; and the extent, distribution and natural vulnerability of the geosites. Preparation of the sample for transport must be performed to ensure the integrity of the material collected and correct identification of the origin, to prevent any misunderstandings that may result in the destruction of scientific samples or loss of relevant information for the study. Similar problems can also occur if the organization and maintenance of scientific collections is not carried out totally in accordance with the museological criteria for the storage and documentation of geological material. Exaggerated or irresponsible sampling can also cause or exacerbate local erosive processes, covering the exposures of interest and affecting the biodiversity which depends on the geodiversity of the region.

- To maximize the scientific value of the samples, collection should be made with great care. All relevant information on the origin of the samples needs to be recorded in detail, such as the original distribution of the samples in plan and section; their position in stratigraphic profiles; GPS coordinates, the orientation and other data location and general geological context (stratigraphic, sedimentary, taphonomic data and top and base of the sample, for example) regarding the sampling points already collected, date and collector's name. These records must be provided with annotations in the field notebook, accompanied by photographs, films, illustrations, maps, profiles, and when possible, a three-dimensional scanning of the geosite. The participation of students should be preceded by the proper training, according to the types of materials that can be found in the studied area and the proper handling of said materials.

\section{SAFETY MEASURES}

- The use of PPE - Personal Protective Equipment (boots, long pants, longsleeved blouses, leggings for snake bite protection, safety goggles, gloves, helmets, clothing with reflective accessories, lotion or sunscreen for UV ray protection, etc.) should be mandatory, considering the place where the work is to be carried out, as well 
as other safety items, such as road safety cones, when the fieldwork occurs along roads.

- All team members should be trained in first aid activities and in the behavior of wildlife (eg. bees, wasps, snakes).

- Researchers responsible for the fieldwork should also provide first aid equipment and copies of telephone numbers of all participants before starting activities. It is essential to know the regional health infrastructure (hospitals, medical centers and emergencies).

- To prevent accidents, the team leader should conduct a preliminary survey of the poisonous plants and animals living in the area of the geosite, warning the team in advance. The team leader should guide the members of the group to carefully verify, with the help of hammer or other equipment, the blocks on the ground or cracks, to identify the possible presence of dangerous animals hidden in these sites.

- Before starting to collect materials, unstable sections of the outcrop should always be carefully analyzed, as blocks of rock can move suddenly and cause injuries to team members. Rocky cliffs with frequent (or recent) evidence of collapse of blocks should be avoided or approached paying particular attention to safety conditions.

- If the sampling is done with hammers or other equipment, the location of other researchers should be noted and an appropriate exclusion zone established to prevent rocky splinters that may be generated from reaching eyes or other parts of the body.

- On outcrops located on the coast, the table of tides released by the Brazilian Navy Diretoria de Hidrografia e Navegação (Directorate of Hydrography and Navegation) must be consulted beforehand, especially in regions where great variations of tidal level occur, e.g. the North and Northeast of Brazil. Lifejackets must be worn during the work conducted on rocky cliffs along the sea or on riverbanks.

- Whenever a researcher is working alone, he or she must inform another person or the authorities on route to the site and upon returning.

- In remote areas, guides should be recruited in order to assist in the tour of the team. The group should inform someone as to the planned route of the fieldwork, the number of members of the group and the day and time scheduled for return.

- In mining areas companies must be contacted before starting activities in order to obtain information on the risks and safety measures of the site. In addition, researchers must also inform their staff of safety procedures and the personal protective equipment required to perform work on site, as well as the time of entry and exit from the site. Approaching areas using vehicles and/or machinery should be avoided.

- In the case of underground activities (i.e. in caves) proper equipment must be used, and specific training and support from an expert guide are also indispensable.

\section{CONCLUSIONS - A CODE UNDER CONSTRUCTION}

The publication and distribution of the proposal for a code of conduct aim to test the response of researchers to the 29 items proposed in our guidelines. It encourages the debate on responsible behavior during fieldwork, following an approach based on geoethics, geoconservation, and sustainability values. In this way, all Brazilian geoscientists may contribute to the preservation of 
our geological heritage and of outcrops with special educational relevance.

Moreover, a debate on a Brazilian code of conduct for fieldwork in Geology may also stimulate a broader discussion on Geoethics and Geoconservation in Brazil. This is a matter that should be addressed by technical and scientific organizations and the Geological Survey of Brazil in order to promote long overdue discussion; as actions having social and environmental repercussions should be carefully considered by all people, including citizens and scientists alike.

\section{REFERENCES}

BIRKBECK COLLEGE. 2016. Fieldwork Safety Code of Practice. Birkbeck College Safety Officer Available: http:// www.bbk.ac.uk/geology/downloads/fieldsafetyguide.pdf. Last accessed December 2016.

BRASIL. 1942. Decreto-Lei no 4146 de 4 de março de 1942. Available: http://www.dnpm.gov.br/conteudo.asp?IDSe $\mathrm{cao}=67 \&$ IDPagina $=84 \&$ IDLegislacao $=2$. Last accessed November 2016.

BRASIL. 1990a. Decreto no 98.830 de 15 de janeiro de 1990. Available: http://www.icmbio.gov.br/sisbio/images/ stories/instrucoes_normativas/98830_90.pdf. Last accessed November 2016.

BRASIL. 1990b. Portaria MCT No 55, de 14 de março de 1990. Available: http://www.dnpm.gov.br/conteudo.asp $?$ IDSecao $=67 \&$ IDPagina $=84 \&$ IDLegislacao $=198$. Last accessed November 2016.

BRASIL. 2000. Lei No 9.985, de julho de 2000. Available: http://www.planalto.gov.br/ccivil_03/Leis/L9985.htm. Last accessed November 2016.

BRILHA J. 2016. Inventory and Quantitative Assessment of Geosites and Geodiversity Sites: a Review. Geoheritage 8: 119-134.

BUTLER R. 2015. Destructive sampling ethics. Nat Geosci 8: 817-818.

CACHÃO M AND SILVA CM. 2004. Introdução ao Património Paleontológico Português: definições e critérios de classificação. Geonovas 18: 13-19.

DNPM. 2010. Parecer No 107/2010/FM/PROGE/DNPM de 23 de abril de 2010. Available: http:/www.dnpm.gov.br/ mostra_arquivo.asp?IDBancoArquivo Arquivo=4106. Last accessed November 2016.

FEDONKIN MA, IVANTSOV AY, LENOV MV, LIPPS JH, SEREZHNIKOVA EA, MALYUTIN EI AND KHAN YV. 2009. Paleo-piracy endangers Vendian (Ediacaran) fossils in the White Sea - Arkhangelsk region of Russia. In: Lipps
JH and Granier BRC (Eds), PaleoParks - The protection and conservation of fossil sites worldwide, Carnets de Géologie/Notebooks on Geology, p. 103-111.

FURUKAWA GG, RAMOS RRC, AND BOIÇA WAL. 2010. "Resgate Geológico" de afloramento da Bacia de Macacu em perigo de desaparecimento no bairro de Santa Cruz da Serra, Duque de Caxias/RJ. In: $45^{\circ}$ Congresso Brasileiro de Geologia, 2010. Anais $45^{\circ}$ Congresso Brasileiro de Geologia, Belém.

GEOLOGISTS' ASSOCIATION. 1995. A Code for Geological Fieldwork. London. Available: http://www.amlwchhistory. co.uk/parys/geology $\% 20$ field $\% 20$ work $\% 20$ code.pdf. Last accessed December 2016.

GRUNWALD A. 2015. The Imperative of Sustainable Development: Elements of an Ethics of Using Georesources Responsibly. In: Wyss M and Peppoloni S (Eds), Geoethics Ethical Challenges and Case Studies in Earth Sciences, p. 25-35.

IAPG. 2012. What is Geoethics? International Association for Promoting Geoethics (IAPG). Available: http://www. geoethics.org/geoethics. Last accessed December 2016.

LISLE RJ, BRABHAM P AND BARNES J. 2014. Basic Geological Mapping. J Wiley \& Sons, Ltd, The Atrium, Southern Gate, Chichester. $5^{\text {th }}$ ed., 221 p.

MACFADYEN C. 2007. Coreholes: a widespread problem. Earth Heritage 28: 17.

MACFADYEN C. 2008. Test bed: Fossil-rich former quarry is ideal proving ground for new Code. Earth Heritage 30: 17-18.

MACFADYEN C. 2011a. A Living Fossil Code. Earth Heritage 36: 22-24.

MACFADYEN C. 2011b. Irresponsible coring: new guidelines and establishing a methodology for outcrop restoration. Earth Heritage 36: 11-12.

MANSUR KL. 2010. Ordenamento territorial e geoconservação: análise das normas legais aplicáveis no Brasil e um caso de estudo no estado do Rio de Janeiro. Geociências 29: 237-249.

MANSUR KL, PONCIANO LCMO, CASTRO ARSF AND CARVALHO IS. 2013. Conservação e restauro do patrimônio geológico e sua relevância para a geoconservação. Boletim Paranaense de Geociências 70: 137-155.

MCGOWAN AJ AND CHALLANDS T. 2013. Saving the fishes from city streetlife! Earth Heritage 39: 27-28.

NORTHERN IRELAND ENVIRONMENT AGENCY. 2013. Causeway Coast and World Heritage Site Management Plan 2013 - 2019, 55 p. Available http://giantscauseway. ccght.org/wp-content/uploads/2014/02/2013-2019-WHSManagement-Plan.pdf. Last Accessed January, 2017.

PEPPOLONI S AND DI CAPUA G. 2012. Geoethics and geological culture: awareness, responsibility and challenges. Ann Geophys 55: 335-341. 
PEPPOLONI S AND DI CAPUA G. 2016. Geoethics: Ethical, social, and cultural values in geosciences research, practice, and education. In: Wessel G and Greenberg J (Eds), Geoscience for the Public Good and Global Development: Toward a Sustainable Future. Geological Society of America, Special Paper 520, p. 17-21.

PEREIRA RF, BRILHA J AND MARTINEZ J E. 2008. Proposta de enquadramento da geoconservação na legislação ambiental brasileira. Memórias e Notícias 3: 491-494.

PONCIANO LCMO, CASTRO ARSF, MACHADO DMC, FONSECA VMM AND KUNZLER J. 2011. Patrimônio Geológico-Paleontológico in situ e ex situ: Definições, vantagens, desvantagens e estratégias de conservação. In: Carvalho et al. (Eds), Paleontologia: Cenários de Vida. Editora Interciência, v. 4, p. 853-869.

RAWORTH K. 2012. A safe and just space for humanity: can we live within the doughnut? Oxfam Discussion Paper: $1-25$.

ROWAN C. 2008. Archean bacterial mats under the hammer. News \& Commentary from the World of Geology \& Earth Science. Available http://all-geo.org/ highlyallochthonous/2008/05/archean-bacterial-matsunder-the-hammer/. Last Accessed December, 2016.

SCOTTISH NATURAL HERITAGE. 2016. Scottish Fossil Code. Available http://www.snh.org.uk/pdfs/fossil_code/ fossilcode_08.pdf. Last accessed December, 2016.
SOUZA AR, MACHADO DMC, PONCIANO LCMO, FARIA ACG, VIEIRA ACM AND PINTO FM. 2007. Geoconservação: a preservação e valorização do patrimônio geológico. In: Carvalho et al. (Eds), Paleontologia: Cenários de Vida. Editora Interciência 2: 79-88.

STOCK-DA-ROSA AA, SCHERER CS AND BLANCO CC. 2003. Salvamento Paleontológico na linha de transmissão de energia elétrica Uruguaiana - Santa Rosa. In: Boletim Paleontologia em Destaque 44: 8 .

UNIVERSITY OF BRISTOL. 2016. Student declaration form for field safety and medical fitness. Available http:/www. gly.bris.ac.uk/www/ugrad/newstudents/Declaration Form.pdf. Last accessed December, 2016.

UNIVERSITY OF NOTTINGHAM. 2016. Policy \& Guidance for the Safe Conduct of Fieldwork. Available http://www. nottingham.ac.uk/safety/documents/fieldwork-policy.pdf. Last accessed December, 2016.

UNIVERSITY OF READING. 2016. Safety Code of Practice 32: Fieldwork, Available https://www.reading.ac.uk/ web/files/health-and-safety/CoP_32_Fieldwork.pdf. Last accessed December, 2016.

VASCONCELOS CM AND IMBERNON R. 2015. Geoética no caminho da educação para o desenvolvimento sustentável. In: VI Simpósio Nacional de Ensino e História de Ciências da Terra. Proceedings... Campos do Jordão. SBG, p. 578-582. 